\title{
PENENTUAN POLA KELELAHAN FISIK PADA PEROKOK AKTIF DENGAN MENGGUNAKAN METODE RESPONSE SURFACE METHODOLOGY (Studi Kasus: Mahasiswa PS. Teknik Industri UIN Sunan Kalijaga)
}

\author{
Tutik Farihah ${ }^{*}$ \\ Prodi Teknik Industri, UIN Sunan Kalijaga \\ Jl. Marsda Adisucipto Yogyakarta
}

(Received: September 30, 2015 / Accepted: May 25, 2016)

\begin{abstract}
Abstrak
Penelitian ini bertujuan untuk mengidentifikasi pola kelelahan fisik pada perokok aktif baik di beban kerja ringan, menengah dan beban kerja yang berat dengan faktor suhu dan cahaya. Response Permukaan Metodologi ( RSM ) adalah kumpulan teknik statistik dan matematika yang berguna untuk evaluasi hubungan yang ada pada beberapa faktor kuantitatif terhadap variabel respon. Berdasarkan hasil pengolahan data pada beban kerja ringan dan beban kerja menengah memiliki fungsi pola pelana. Sedangkan pada beban kerja berat memiliki fungsi respon permukaan minimum.
\end{abstract}

Kata Kunci: RSM; beban kerja

\begin{abstract}
This study aims to identify workload pattern in active smokers both in light workload, medium and heavy workload with controlled faktor are temperature and light.Response Surface Metodology (RSM) is a collection of statistical and mathematical techniques useful for evaluation of relationship existing between some controlled experiment faktors and measured responses according to one or more selected criteria. Based on the results on light workload optimization functions have saddle pattern functions so it is with medium workload. While the heavy workload optimization functions are obtained based on the minimum surface.
\end{abstract}

Keyword: RSM; workload

\section{Pendahuluan}

Hampir 1 juta milyar khususnya laki-laki merokok dengan prosentase $35 \%$ berada di negara maju, $50 \%$ tinggal di negara berkembang dan sisanya berada di negara miskin. Sedangkan perempuan memiliki angka yang tidak jauh berbeda yakni 250 juta dengan $22 \%$ berada di negara maju, $9 \%$ negara berkembang. Rendahnya tingkat konsumsi tembakau pada perempuan tidak mencerminkan kesadaran akan kesehatan, namun lebih kepada tradisi sosial dan rendahnya pendapatan ekonomi pada perempuan. Jumlah ini akan terus bertambah karena pengaruh pertambahan jumlah populasi. Pada tahun 2030 akan ada sekitar 2 milyar orang di dunia. Meskipun angka prevalensi ini salah, jumlah perokok akan tetap

\footnotetext{
${ }^{*}$ Penulis Korespondensi. email: tutik_farihah@yahoo.com
}

Jurnal Teknik Industri, Vol. XI, No. 2, Mei 2016 meningkat. Konsumsi tembakau telah mencapai proporsi epidemik global (Mackay \& Eriksen, 2002). Indonesia adalah salah satu negara konsumen tembakau terbesar dunia dimana konsumsi rokok secara nasional mencapai 182 milyar batang pada tahun 2002 dan menduduki peringkat ke 5 negara dengan konsumsi tembakau pada tahun 2004 telah bergeser menjadi ke-3 pada tahun 2008 (WHO dalam Prabandari dkk, 2009).

Poerwadarminta (1995) mendefinisikan merokok sebagai menghisap rokok sedangkan rokok sendiri adalah gulungan tembakau yang berbalut daun nipah atau kertas. Merokok adalah menghisap asap tembakau yang dibakar ke dalam tubuh dan menghembuskannya kembali keluar (Armstrong, 1990). Sedangkan berdasarkan jumlah rokok yang dikonsumsi per hari dapat diklasifikasikan sebagai perokok ringan (1- 4 batang), sedang (5-14 batang), perokok berat (lebih dari 15 batang) (Smet, 1994). 
Dalam satu batang rokok mengandung sekitar 3.000 macam zat kimia, 3 diantaranya: nikotin, karbonmonoksida dan tar. Nikotin merangsang pelepasan adrenalin, meningkatkan frekuensi denyut jantung, tekanan darah, kebutuhan oksigen jantung, serta menyebabkan gangguan irama jantung. Kabonmonoksida dapat menikat Haemoglobin sehingga oksigen tidak dapat di edarkan ke seluruh tubuh dan organ tubuh tidak dapat berfungsi. Tar sebagai zat terakhir merupakan zat yang bersifat karsinogenik (memicu kanker)(Mandagi, 1996). Kondisi kesehatan akibat merokok berpengaruh terhadap produktifitas seseorang. Dengan menggunakan ukuran kesehatan objektif yang berupa kapasitas paru-paru individu, ditunjukkan bahwa kapasitas paru-paru berpengaruh positif terhadap jam kerja individu per minggu. Semakin besar kapasitas paru-paru, semakin lama jam kerja individu, dan semakin kecil kapasitas paru-paru akibat merokok maka akan semakin cepat seseorang mengalami kelelahan.

Selain faktor internal, kondisi lingkungan kerja juga sangat berpengaruh terhadap kinerja seseorang baik secara langsung maupun tidak langsung Kondisi mikroklimat, kebisingan, getaran, penerangan dan kualitas udara yang melebihi nilai ambang batas atau standar yang telah direkomendasikan, dapat memperlemah fungsi tubuh, menurunkan kinerja dan pada akhirnya menurunkan produktivitas kerja. (Manuaba, 2000; Astrand \& Rodahl, 1997).

Menurut Oesman (2010) kerja manual dan berulang-ulang pada kondisi lingkungan yang panas merupakan salah satu faktor yang berpotensi meningkatkan beban kerja fisik dan terjadinya kecelakaan kerja sehingga dapat menimbulkan penyakit akibat kerja (keluhan muskuloskeletal dan kelelahan). Untuk mengetahui tingkat kelelahan kerja akibat aktivitas fisiologis selama bekerja dapat dilakukan dengan melakukan pengukuran denyut jantung(Christensen, 1991), konsumsi oksigen (Molen et al., 2007) dan tekanan darah (Hsu et al., 2008; Abdelhamid \& Everett, 2002).

Response Surface Methodology(RSM) adalah sekumpulan metode-metode matematika dan statistika yang digunakan dalam permodelan dan analisis dan bertujuan untuk melihat pengaruh beberapa variabel kuantitatif terhadap variabel respon dan untuk mengoptimalkan variabel respon tersebut (Montgomery, 2001). Metode ini dikembangkan oleh Box dan Wilson tahun 1951 dan telah digunakan secara luas dalam manufaktur diantaranya: penentuan parameter desain(Khuri,2010), multibody system(Etman, 1997), optimisasi pembentukan sheetmetal (Jansson, 2005), optimisasi crashworthiness(Redhe, 2004), optimisasi sudut pengecoran(Gustafsson, 2008).

Jurnal Teknik Industri, Vol. XI, No. 2, Mei 2016

\section{Metode}

Rancangan percobaan penentuan tingkatan suhu dan pencahayaan dilakukan dengan menggunakan metode Response Surface Methodology. Dalam RSM terdapat enam tahapan yakni: pemilihan variabel independent dan variabel respon, pemilihan desain eksperimen yang digunakan, pengambilan data, permodelan hasil eksperimen, identifikasi, bentuk respon dan verifikasi model(ANOVA), penentuan kondisi optimum.

Pada tahapan pemilihan variabel independent, variabel suhu $\left(\mathrm{X}_{1}\right)$, cahaya $\left(\mathrm{X}_{2}\right)$ di nyatakan sebagai variabel independent. Pada suhu berada pada kisaran $14 \mathrm{C}$ hingga $35 \mathrm{C}$, sedangkan untuk cahaya dilakukan penelitian dengan kisaran 150 Lux - 995 Lux.

Pada tahap penentuan desain eksperimen, rancangan untuk model orde pertama menggunakan orthogonal first order (desain faktorial dua level dengan empat center point). Pendekatan first order model ditunjukkan dengan persamaan berikut:

$y=\beta_{0}+\beta_{1} x_{1}+\beta_{2} x_{2}+\ldots+\beta_{k} x_{k}+\varepsilon_{i}$

Sedangkan untuk rancangan untuk model orde kedua menggunakan metode Central Composite Design (CCD) atau Box Behken design dengan $4 \mathrm{n}_{\mathrm{f}}, 4$ aksial dan centre point dengan persamaan :

$y=\beta_{0}+\sum_{i=1}^{k} \beta_{i} x_{i}+\sum_{i=1}^{k} \beta_{i i} x_{i}^{2}+\ldots+\sum_{i<j} \sum \beta_{i j} x_{i} x_{j}+\varepsilon$

Tahapan selanjutnya adalah pengambilan data. Kriteria inkulasi responden adalah responden merupakan perokok aktif, mahasiswa teknik industri UIN Sunan Kalijaga, berumur 18 - 30 tahun (semester 4 keatas) dan tidak memiliki riwayat sakit jantung. Tiap responden akan berlari di treadmill selama 4 menit dan diukur denyut nadi pada akhir menit ke-empat untuk menentukan denyut nadi kerja kemudian istirahat 1 menit untuk diukur denyut nadi istirahat responden. Denyut nadi kerja dan istirahat di ukur dengan menggunakan sensor pada treadmill. Pengambilan data di lakukan di Laboratorium Ergonomi dan analisis perancangan kerja UIN Sunan Kalijaga.

Tahap permodelan hasil eksperimen dan identifikasi bentuk respon pada RSM terdiri atas dua tahap yakni: pemberian kode data hasil eksperimen dan permodelan dengan regresi linear. RSM menggunakan kode $-1,0$ dan +1 bukan dengan nilai asli faktor (Daneshi et al, 2010). Penentuan kode menggunakan persamaan sebagai berikut: $x_{i}=\frac{x_{i}-x_{C O}}{\Delta x_{i}}$

Tahap verifikasi model menggunakan ANOVA untuk menyimpulkan apakah model yang terbentuk akurat dan tingkat signifikansi tiap faktor independent terhadap variabel respon. Pengolahan data dilakukan dengan menggunakan software Minitab v.17.0. pada Oder I, signifikansi faktor dan model regresi linear dilihat berdasarkan nilai $\mathrm{p}$-value dan $R^{2}$. 
Sedangkan pada Orde II, signifikansi model dilihat berdasarkan uji kesesuaian model regresi (Lack of Fit) dan uji para meter regresi secara serentak. Dalam uji regresi akan dilihat nilai $p$-value pada individu faktor untuk melihat pengaruhnya terhadap variabel respon. Hipotesis uji keseuaian model regersi:

$\mathrm{H}_{0}$ : Model regresi cocok (tidak ada lack of fit)

$\mathrm{H}_{1}$ : Model regresi tidak cocok (ada lack of fit)

dengan dasar pengambilan keputusan, apabila nilai $p$ value lebih dari $\alpha$ maka Ho diterima dan dinyatakan bahwa model regresi cocok.

Sedangkan hipotesis yang digunakan dalam uji parameter regresi secara serentak adalah:

$\mathrm{H}_{0}: \beta_{\mathrm{i}}=0, \mathrm{I}=1,2,3, . . \mathrm{k}$

$\mathrm{H} 1$ : Paling tidak ada satu $\beta \mathrm{j}$ yang tidak sama dengan nol dengan dasar pengambilan keputusan, apabila nilai $\mathrm{F}$ hitung lebih dari $\mathrm{F}$ tabel maka Ho ditolak dan dinyatakan bahwa variabel-variabel independen memberikan sumbangan bagi terbentuknya model.

Tahap penentuan pola/kondisi optimim dilakukan dengan melihat grafik respons yang telah terbentuk.

\section{Hasil Dan Pembahasan}

Pada penelitian ini responden yang terlibat sejumlah 26 orang dan merupakan mahasiswa teknik industri. Keseluruhan responden berjenis kelamin laki-laki dan merupakan perokok aktif kategori ringan dengan kurang dari 10 batang rokok yang di hisap tiap hari. RSM digunakan untuk menggambarkn pola non linear antara faktor terkontrol dengan variabel respon. Apabila model kelelahan fisik telah dapat digambarkan dengan bentuk model regresi linear(nilai p-value persamaan $<\alpha$ dan nilai $\mathrm{R}^{2}$ ) maka pengolahan tidak dilanjutkan pada orde II.

Pada penentuan model orde satu digunakan metode regresi linear dengan pendekatan least square. Nilai $\alpha=0.05(5 \%)$ dengan nilai $\mathrm{F}$ tabel:3.42. Untuk beban kerja ringan responden berjalan selama 4 menit dengan kecepatan $3,2 \mathrm{~km} / \mathrm{jam}$. Selanjutnya responden akan dicatat denyut nadi pada akhir menit keempat. Hasil pencatatan denyut nadi diolah dengan menggunakan software Minitab v.17.0. Permodelan hasil denyut nadi pada beban kerja ringan dapat dilihat pada Tabel 1 .

Tabel 1. ANOVA dan Persamaan model orde satu

\begin{tabular}{lllll}
\hline Beban & $P$ & $F$ & $\mathrm{R}^{2}$ & Persamaan \\
Kerja & value & value & & \\
\hline Ringan & 0.986 & 0.01 & 0.46 & $107.44-0.25 \mathrm{X}_{1}-1.25 \mathrm{X}_{2}$ \\
Sedang & 0.979 & 0.02 & 0.70 & $142.22-0.75 \mathrm{X}_{1}+0.25 \mathrm{X}_{2}$ \\
Berat & 0.147 & 2.69 & 47.27 & $169.22+7.5 \mathrm{X}_{1}+6.5 \mathrm{X}_{2}$ \\
\hline
\end{tabular}

Berdasarkan Tabel 1 untuk beban kerja ringan dapat diketahui nilai $\mathrm{p}$ value $(0.986)>(\alpha=5 \%)$ yang artinya semua faktor tidak signifikan secara statistik.
Model tidak signifkan juga dapat dilihat dari rendahnya nilai $R$ square dan rendahnya nilai $\mathrm{F}$ value persamaan pada analisis ANOVA. Sehingga model persamaan orde satu:

$\mathrm{y}=107.44-0.25$ suhu -1.25 cahaya

dapat dinyatakan tidak sesuai/ tidak signifikan untuk menggambarkan kelelahan fisik perokok ringan pada beban kerja ringan atau hubungan antara faktor terkontrol suhu dan cahaya terhadap keleahan fisik responden tidak berbentuk linear. Oleh karena itu pembentukan model dilanjutkan pada model orde II. Pada beban kerja sedang responden(perokok aktif kategori ringan) berlari selama 4 menit dengan kecepatan 6,4 km/jam . Berdasarkan Tabel 1 dapat diketahui nilai $\mathrm{p}$ value $(0.979)>5 \%$ yang artinya semua faktor tidak signifikan secara statistik. Model tidak signifikan juga dapat dilihat dari rendahnya nilai $\mathrm{R}$ square $(0,70 \%)$ dan rendahnya nilai $\mathrm{F}$ value persamaan pada analisis $\operatorname{ANOVA}(0,02)$. Sehingga model persamaan orde satu:

$\mathrm{y}=142.22-0.75$ suhu +0.25 cahaya dapat dinyatakan tidak sesuai/ tidak signifikan untuk menggambarkan kelelahan fisik perokok ringan aktif pada beban kerja menengah atau hubungan antara faktor terkontrol suhu dan cahaya terhadap kelelahan fisik responden tidak berbentuk linear. Oleh karena itu permodelan data dilanjutkan pada model orde II

Pada beban kerja berat responden berlari selama 4 menit dengan kecepatan $9.6 \mathrm{~km} / \mathrm{jam}$. Berdasarkan Tabel 1 dapat diketahui nilai $\mathrm{p}$ value $(0.147)>5 \%$ yang artinya semua faktor tidak signifikan secara statistik. Model tidak signifikan juga dapat dilihat dari rendahnya nilai $R$ square $(47,27 \%)$ dan rendahnya nilai $\mathrm{F}$ value persamaan pada analisis ANOVA(2.69). Sehingga model persamaan orde I: $(\mathrm{y}=169.22+7.50$ cahaya $+6.50 \mathrm{suhu})$ dapat dinyatakan tidak sesuai/ tidak signifikan untuk menggambarkan kelelahan fisik perokok ringan pada beban kerja berat atau hubungan antara faktor terkontrol suhu dan cahaya terhadap keleahan fisik responden tidak berbentuk linear dan dapat dilanjutkan pada model orde II.

Desain CCD pada model orde dua menggunakan dua variabel independen sehingga nilai rotatabilitasnya $=1,41421$. Dengan menggunakan persamaan (2) maka dapat diperoleh kode dan level tiap variabel pada Tabel 2 .

Tabel 2. Kode level vs Nilai level

\begin{tabular}{llllll}
\hline Kode & \multicolumn{1}{c}{-} & -1 & 0 & 1 & 1,41421 \\
Level & 1,41421 & & & & \\
$\mathrm{X}_{1}$ & 10,274 & 14 & 23 & 32 & 35,726 \\
$\mathrm{X}_{2}$ & 5,1 & 150 & 500 & 850 & 994,9 \\
\hline
\end{tabular}

Prosedur pengujian dengan menggunakan uji kesesuaian model regresi (lack of Fit) dan uji parameter regresi secara serentak. Uji Koefisien/ 
determinasi ganda digunakan untuk mengetahui keterwakilan data dalam model(Sugiyono, 2007)

1. Beban Kerja Ringan

Tabel 3. Estimasi Koefisien persamaan model beban kerja ringan

Analysis of Variance

$\begin{array}{lrcccc}\text { Source } & \text { DF } & \text { Adj SS Adj MS F-Value } & \text { P-Value } \\ \text { Model } & 5 & 1296.13 & 259.23 & 7.24 & 0.011 \\ \text { Linear } & 2 & 512.99 & 256.49 & 7.16 & 0.020 \\ \quad \text { suhu } & 1 & 403.27 & 403.27 & 11.26 & 0.012 \\ \quad \text { cahaya } & 1 & 109.72 & 109.72 & 3.06 & 0.123 \\ \text { Square } & 2 & 752.89 & 376.45 & 10.51 & 0.008 \\ \quad \text { suhu*suhu } & 1 & 603.29 & 603.29 & 16.85 & 0.005 \\ \quad \text { cahaya*cahaya } & 1 & 235.03 & 235.03 & 6.56 & 0.037 \\ \text { 2-Way Interaction } & 1 & 30.25 & 30.25 & 0.84 & 0.389 \\ \quad \text { suhu*cahaya } & 1 & 30.25 & 30.25 & 0.84 & 0.389 \\ \text { Error } & 7 & 250.64 & 35.81 & & \\ \text { Lack-of-Fit } & 3 & 82.64 & 27.55 & 0.66 & 0.620 \\ \text { Pure Error } & 4 & 168.00 & 42.00 & & \\ \text { Total R-sq } & 12 & 1546.77 \\ \text { R-sq(adj) } & \text { R-sq(pred) } & & \\ \text { 5.98374 83.80\% } & 72.22 \% & 45.04 \% & & \end{array}$

Pada Tabel 3. dapat diketahui nilai p-value uji lack of fit terhadap model adalah 0,620 atau lebih besar daripada derajat signifikansi $(0,05)$ sehingga $\mathrm{H}_{\mathrm{o}}$ dapat diterima atau model regresi yang terbentuk cocokj. Sedangkan untuk nilai $\mathrm{F}$ hitung pada uji parameter regresi secara serentak di peroleh 7,24 atau lebih besar dari nilai $F$ Tabel sehingga dapat disimpulkan variabel-variabel independen memberikan sumbangan yang berarti pada model. Ketepatan model juga di tunjukkan dengan tingginya nilai $R$-square model yakni $83,80 \%$ yang berarti bahwa model signifikan/ berkorelasi kuat dalam mewakili data. Sedangkan variabel yang signifikan mempengaruhi hasil adalah $\mathrm{x}_{1}, \mathrm{x}_{1}^{2}$ dan $\mathrm{x}_{2}^{2}$ dan variabel yang tidak signifikan adalah $\mathrm{x}_{2}, \mathrm{x}_{1} \mathrm{x}_{2}$. Sehingga dapat dinyatakan pada beban kerja ringan, model kelelahan dengan variabel independen suhu dan cahaya adalah sebagai berikut:

$\mathrm{DNK}=102.00+7.10$ suhu +3.70 cahaya +9.31 suhu*suhu +5.81 cahaya*cahaya

- 2.75 suhu*cahaya.

Penentuan nilai respon optimum dilakukan dengan melihat bentuk respon yang ada. Bentuk respon permukaan dapat dilihat pada Gambar 1 .

Berdasarkan Gambar 1. bentuk permukaan respon kelelahan perokok dengan beban kerja ringan minimum dengan kecenderungan berbentuk pelana karena tidak membentuk parabola sempurna. Denyut nadi berada pada range 120 hingga 125 pada saat suhu tinggi. Sehingga denyut nadi akan meninggi saat suhu mengalami kenaikan Titik stationer model orde dua yang disusun berdasarkan model regresi orde kedua

Jurnal Teknik Industri, Vol. XI, No. 2, Mei 2016 berada pada nilai denyut nadi sebesar 99,659 berada pada suhu $19,09^{\circ}$ Celcius dan cahaya 351,873 Lux

2. Beban Kerja Sedang/Menengah

Contour plot beban kerja ringan

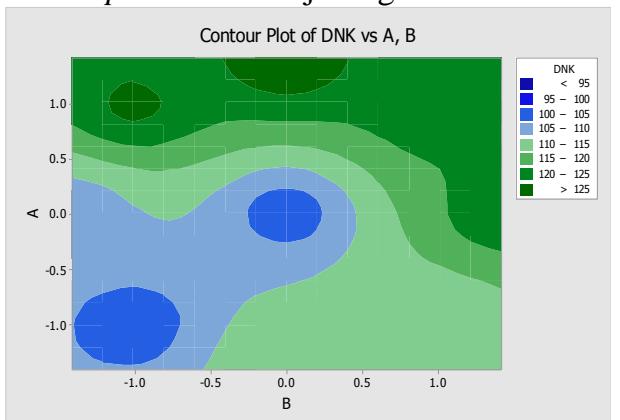

Surface plot beban kerja ringan

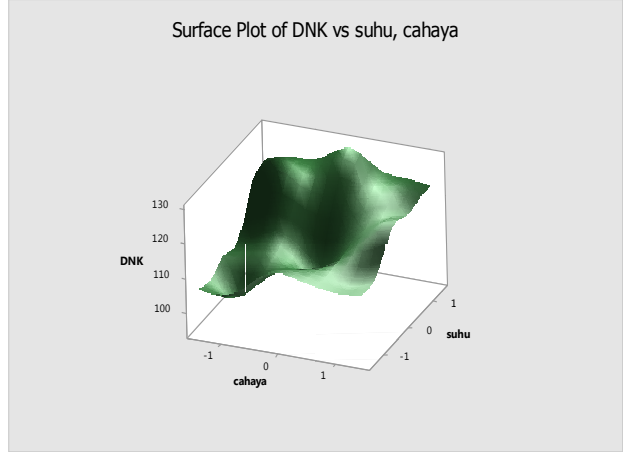

Gambar 1. Surface Plot dan Contour Plot Beban Kerja Ringan

Tabel 4. Estimasi Koefisien persamaan model beban kerja Sedang/ Menengah

\begin{tabular}{lccccr}
\multicolumn{2}{l}{ Analysis of Variance } & \multicolumn{1}{l}{} \\
Source & DF & Adj SS & Adj MS & F-Value & P-Value \\
Model & 5 & 603.16 & 120.63 & 6.03 & 0.018 \\
Linear & 2 & 459.50 & 229.75 & 11.49 & 0.006 \\
Suhu & 1 & 225.31 & 225.31 & 11.27 & 0.012 \\
Cahaya & 1 & 234.19 & 234.19 & 11.72 & 0.011 \\
Square & 2 & 113.40 & 56.70 & 2.84 & 0.125 \\
Suhu*Suhu & 1 & 93.31 & 93.31 & 4.67 & 0.068 \\
Cahaya*Cahaya 1 & 32.53 & 32.53 & 1.63 & 0.243 \\
2-Way Interaction 1 & 30.25 & 30.25 & 1.51 & 0.258 \\
Suhu*Cahaya & 1 & 30.25 & 30.25 & 1.51 & 0.258 \\
Error & 7 & 139.92 & 19.99 & & \\
Lack-of-Fit & 3 & 37.12 & 12.37 & 0.48 & 0.713 \\
Pure Error & 4 & 102.80 & 25.70 & & \\
Total & 12 & 743.08 & & & \\
S R R-sq & R-sq(adj) & R-sq(pred) & \\
4.47088 81.17\% & $67.72 \%$ & $42.86 \%$ & &
\end{tabular}

Pada Tabel 4. dapat diketahui nilai p-value uji lack of fit terhadap model adalah 0,713 atau lebih besar daripada derajat signifikansi sehingga dapat dinyatakan Ho diterima atau model regresi cocok(tidak ada lack of fit) Sedangkan untuk nilai F hitung pada uji parameter regresi secara 
serentak di peroleh 6.03 atau lebih besar dari nilai F Tabel sehingga dapat disimpulkan variabelvariabel independen memberikan sumbangan yang berarti pada model. Variabel independen yang signifikan mempengaruhi hasil adalah $\mathrm{x}_{1}$ dan $\mathrm{x}_{2}$ dengan variabel yang tidak signifikan adalah $\mathrm{x}_{1}{ }^{2} \mathrm{x}_{2}{ }^{2}$ dan $\mathrm{x}_{1} \mathrm{x}_{2}$. Ketepatan model juga di tunjukkan dengan tingginya nilai $R$-square model yakni $81.17 \%$ sehingga dapat dinyatakan pada beban kerja ringan, model kelelahan dengan variabel independen suhu dan cahaya adalah sebagai berikut:

DNK $=138.80+5.31$ suhu +5.41 cahaya +3.66 suhu*suhu +2.16 cahaya*cahaya - 2.75 suhu*cahaya

Penggambaran bentuk permukaan respon perokok dengan beban kerja sedang/menengah dapat di lihat pada Gambar 2.

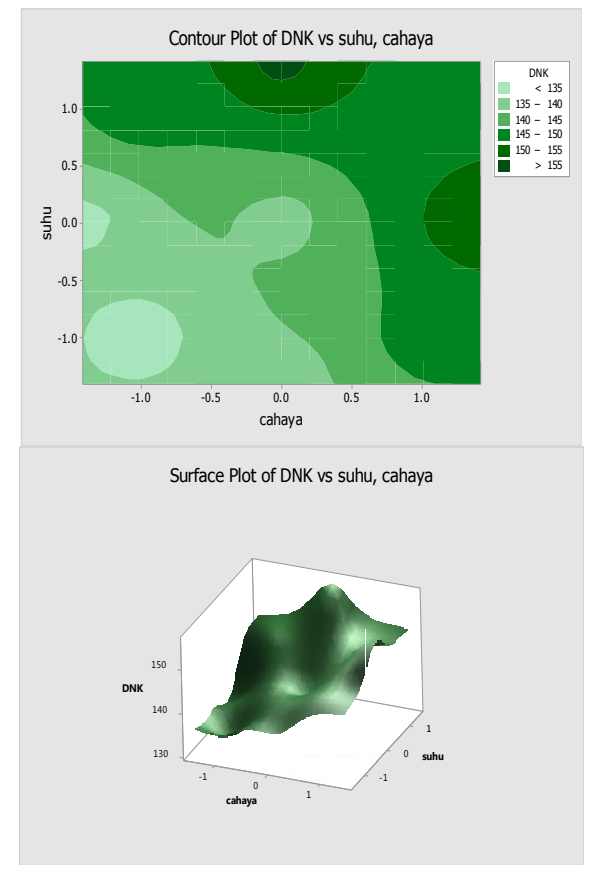

Gambar 2. Control Plot dan Surface plot beban kerja Menengah

Gambar 2 bentuk permukaan respon kelelahan perokok dengan beban kerja sedang/menengah minimum dengan kecenderungan berbentuk pelana karena tidak membentuk parabola sempurna. Denyut nadi berada pada range 150 hingga 155 pada saat suhu tinggi atau cahaya tinggi, karena interaksi faktor memang tidak berpengaruh terhadap hasil.. Sehingga denyut nadi akan meninggi ketika salah satu baik suhu atau cahaya mengalami kenaikan. Titik stationer model orde dua yang disusun berdasarkan model regresi orde kedua berada pada nilai denyut nadi sebesar 128.533 dan berada pada suhu 18.854 ${ }^{\circ}$ Celcius dan cahaya 288.904 Lux

Jurnal Teknik Industri, Vol. XI, No. 2, Mei 2016

\section{Beban Kerja Berat}

Tabel 5. Estimasi Koefisien Persamaan Model beban kerja berat

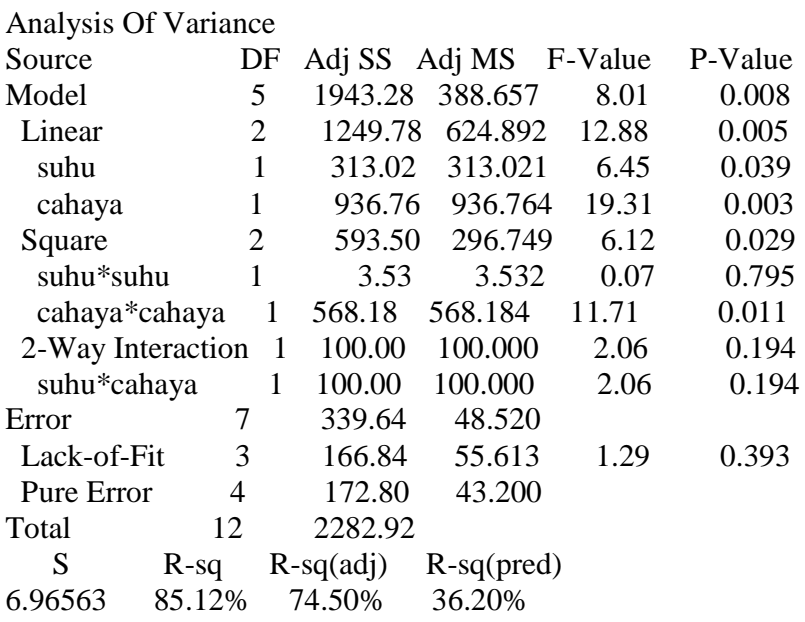

Pada Tabel 5. dapat diketahui nilai p-value uji lack of fit terhadap model adalah 0,393 atau lebih besar daripada derajat signifikansi sehingga dapat dinyatakan Ho diterima atau model regresi cocok(tidak ada lack of fit). Sedangkan untuk nilai F hitung pada uji parameter regresi secara serentak di peroleh 8.01 atau lebih besar dari nilai F Tabel sehingga dapat disimpulkan variabelvariabel independen memberikan sumbangan yang berarti pada model. Variabel independen yang signifikan mempengaruhi hasil adalah $\mathrm{x}_{1}, \mathrm{x}_{2}$ dan $\mathrm{x}_{2}{ }^{2}$ dengan variabel yang tidak signifikan adalah $\mathrm{x}_{1}{ }^{2}$ dan $\mathrm{x}_{1} \mathrm{x}_{2}$. Ketepatan model juga di tunjukkan dengan tingginya nilai $R$-square model yakni $85.12 \%$ mengindikasikan bahwa model memiliki signifikansi tinggi. Sehingga dapat dinyatakan pada beban kerja berat, model kelelahan dengan variabel independen suhu dan cahaya adalah sebagai berikut:

DNK $=173.20+6.26$ suhu +10.82 cahaya +0.71 suhu*suhu $\quad-9.04$ cahaya*cahaya +5.00 suhu*cahaya

Ilustrasi permukaan respon untuk beban kerja berat dapat dilihat pada Gambar 3

Berdasarkan Gambar 3 bentuk permukaan respon kelelahan perokok dengan beban kerja berat cenderung berbentuk minimum. Range denyut nadi lebih dari 170 berada di range suhu tinggi dan cahaya tinggi. Sedangkan denyut nadi $<140$ berada pada suhu normal dan cahaya rendah. Semakin jauh suhu dari suhu normal maka akan semakin tinggi denyut nad/tingkat kelelahan fisik responden, sedangkan pada cahaya semakin tinggi vahaya maka akan semakin tinggi denyut nadi responden. 


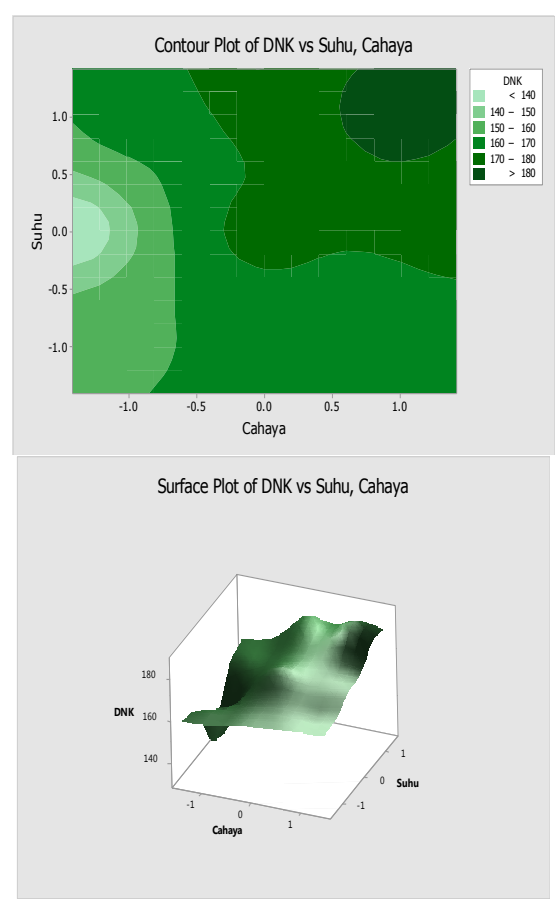

Gambar 3. Contour plot dan Surface Plot Perokok Beban Kerja Berat

\section{Kesimpulan}

Berdasarkan uji ANOVA pada persamaan linear (persamaan orde I) baik beban kerja ringan, beban kerja menengah maupun beban kerja berat pada perokok aktif kategori ringan tidak berbentuk linear. Hal ini dibutikan dengan besarnya nilai $p$-value pada semua kategori beban kerja melebihi nilai $\alpha$ Pada pengolahan data Orde II pada perokok aktif kategori ringan pada beban kerja ringan dan sedang memiliki pola respon kelelahan fisik berbentuk pelana sehingga sangat sulit untuk menentukan titik optimum denyut nadi. . Beban kerja ringan memiliki respon optimum(denyut nadi optimum) sebesar 99,659 berada pada suhu $19,09^{\circ}$ Celcius dan cahaya 351,873 Lux. Sedangkan pada beban kerja sedang titik optimum denyut nadi sebesar 128.533 akan tercapai pada suhu $18.854{ }^{\circ}$ Celcius dan cahaya 288.904 Lux. Sedangkan pada beban kerja berat permukaan respon cenderung berbentuk minimum, semakin jauh suhu dari suhu normal maka akan semakin tinggi denyut nadi//tingkat kelelahan fisik responden

\section{Ucapan Terimakasih}

Penulis mengucapkan terimakasih kepada Khas Khasol (mahasiswa Teknik Industri UIN Sunan Kalijaga) yang telah membantu dalam pengambilan data.

\section{Daftar Pustaka}

Armstrong, M., 1990, Manajemen Sumber Daya Manusia, Jakarta, PT. Gramedia

Jurnal Teknik Industri, Vol. XI, No. 2, Mei 2016
Astrand, P and K. Rodahl, 1971. Textbook of Work Physiology, Hill Book Company, USA.

Christensen, E.H, 1991. Physiology of work. Encyclopedia of Occupational Helath and Safety, Third (revised) ed. ILO, Geneva.

Daneshi,A., Younesi, H., Ghasempouri, S.M., Sharifzadeh., M., 2010, Production of poly -3 hydroxybutirate by cupriavidus necaton from corp syrup: statistical modeling and optimization of biomass yield and volumetric productivity, J. chem., Technol, Biotechnol, 85, 1528- 1539 .

Gustafsson, Erik., Stromberg, Niclas, 2008. Shape Optimization of casting by using Succesive Response Surface Methodology, Structure Multidiscipline Optimization, Springer-Verlag

Heo, Sun Kyung, Lee, Hee Seok, Ha, Sang Do., 2009, A Predictive Model For The Growth Rate of bacillus cereus in Borth by Response Surface Methodology, Journal of Biotechnology and Bioprocess Engineering, pg. $202-206$.

Khuri, A. I., Mukhopadhyay, Siuli, 2010, Response Surface Methodology, WIREs Computational Statistics, John Wiley \& Sons, Inc.

MacKay J, Eriksen M, \& Shafey O. The Tobacco Atlas, Second Edition. The American Cancer Society, Atlanta, USA, 2006.

Mandagi, Jeanne, 1996. Masalah Narkotika dan Zat Adiktif Lainnya serta Penanggulangannya. Jakarta : Bina Darma Pemuda Printing.

Manuaba, A., 2000. Penerapan Ergonomi meningkatakan Produktivitas, Bagian Faal Fakultas Kedokteran Universitas Udayana.

Montgomery, 2001. Design and Analysis of Experiment, John Wiley and Sons Inc.

Oesman, T. 2010. Intervensi Ergonomi pada proses Stamping part Body Component meningkatkan Kualitas dan Kepuasan Kerja serta Efisiensi Waktu di Divisi Stamping Plant PT. ADM Jakarta.

Poerwadarminta, W.J.S, 1995, Kamus Umum Bahasa Indonesia, Jakarta, Balai Pustaka

Prabandari, Yayi Suryo., Ng Nawi, Padmawati, Retna Siwi, 2009, Kawasan Tanpa Rokok Sebagai Alternatif Pengendalian Tembakau Studi Efektivitas penerapan Kebijakan Kampus Bebas Rokok terhadap Perilaku dan Status Meroko Mahasiswa Di Fakultas kedokteran UGM Yogyakarta, Jurnal Manajemen Pelayanan Kesehatan, tersedia online di : http://journal.ugm.ac.id/index.php/jmpk/article /viewFile/2541/2275.

Smet, B., 1994., PsikologiKesehatan, Pt. Gramedia, Semarang

Sugiyono, 2007, Statistika untuk Penelitian, Alfabeta. 